\title{
PENGARUH TEPUNG TELUR AYAM AFKIR PADA PAKAN BUATAN YANG BERPROBIOTIK TERHADAP EFISIENSI PEMANFAATAN PAKAN, PERTUMBUHAN DAN KELULUSHIDUPAN LELE DUMBO (Clarias gariepinus)
}

\section{The Effect Of Chicken Eggs Rejects Powder In Artificial Feed With Added Probiotic On Efficiency Feed Utilization, Growth And Survival Rate Of Dumbo Catfish (Clarias Gariepinus)}

\author{
Suminto*, Titik Susilowati, Bambang Argo Wibowo dan Diana Chilmawati \\ *Departemen Akuakultur, Fakultas Perikanan dan Ilmu Kelautan, Universitas Diponegoro \\ Jl. Prof. Soedarto, SH, Tembalang, Semarang, Jawa Tengah - 50275, Telp/Fax. +62247474698
}

Diserahkan tanggal 14 Oktober 2017, Diterima tanggal 15 Januari 2018

\begin{abstract}
ABSTRAK
Pengembangan budidaya ikan lele, Clarias gariepinus sering terjadi kendala dengan biaya pakan yang terlalu tinggi (60-70\% dari biaya produksi). Barangkali, penggunaan bahan baku lokal seperti pemanfaatan tepung telur ayam yang nilai nutrisinya ting gi, mudah didapat, dan murah harganya merupakan salah satu solusinya. Tujuan penelitian ini adalah untuk mengkaji dan mengetahui pengaruh penambahan tepung telur ayam afkir dalam pakan buatan yang berprobiotik terhadap efisiensi pemanfaatan pakan, pertumbuhan dan kelulushidupan ikan lele dumbo (C. gariepinus). Penelitian ini menggunakan metode eksperimental dengan rancangan acak lengkap (RAL) yang menggunakan 4 perlakuan dan masing-masing 3 kali kali ulangan. Perlakuan itu adalah pakan yang tanpa menggunakan tepung telur ayam afkir (Perlakuan A), pakan yang menggunakan tepung telur afkir masing-masing sebanyak 15\%, 30\%, dan 45\% sebagai Perlakuan B, C, dan D. Ikan uji bibit lele dumbo (C. gariepinus) yang ditebar mempunyai bobot rerata $2.04 \pm 0.05 \mathrm{~g}$ dengan kepadatan 1 ekor/L yang dipelihara selama 42 hari. Variabel data yang diukur meliputi Tingkat Konsumsi Pakan (TKP), Efisiensi Pemanfaatan Pakan (EPP), Feed Convertion Ratio (FCR), Protein Efficiency Ratio (PER), Relative Growth Rate (RGR), dan Survival Rate (SR). Hasil penelitian ditunjukkan bahwa penggunaan tepung telur ayam afkir pada pakan buatan memberikan pengaruh yang nyata $(\mathrm{p}<0.05)$ terhadap TKP, EPP, FCR, PER, dan RGR, tetapi tidak berpengaruh nyata $(\mathrm{P} \geq 0,05)$ terhadap SR. Perlakuan dengan penambahan tepung telur ayam afkir sebanyak 30\% (Perlakuan C) memberikan nilai terbaik untuik TKP sebesar 146,87\%, EPP sebesar $88,77 \%$, PER sebesar 2,61\% dan RGR sebesar 7,65\%/hari dari perlakuan lainnya. Monitoring nilai kualitas air pada media pemeliharaan telah menunjukkan bahwa pada kisaran yang layak untuk pemeliharaan ikan uji.
\end{abstract}

Kata kunci: Pakan ikan lele, Telur ayam afkir, Clarias gariepinus, Pertumbuhan, Kelulushidupan

\section{ABSTRACT}

Catfish cultivation development, Clarias gariepinus often occur constraints with the high cost of feed (60-70\% of the production cost). Perhaps, the use of local raw materials such as the utilization of rejected chicken egg with high nutritional value, easy to obtain, and cheap price is one of the solution. The purpose of this research was to know the effect of addition of rejected chicken egg powder inprobiotized artificial feed on the efficiency of feed utilization, growth and survival rate of catfish, C. gariepinus. This study was used an experimental method with completely randomized design (RAL) by using 4 treatments and each of them 3 replications. The treatments were feed without use of rejected chicken egg powder (Treatment A), feed using 15\%, 30\%, and 45\% of powder meals of rejected chicken egg as treatment B, C, and D, respectively. Catfish, C. gariepinus seeds were stocked with a mean weight of $2.04 \pm$ $0.05 \mathrm{~g}$ with a density of 1 tail / L and cultured for 42 days. The data variables measured were Total of Feed Consumption (TFC), Feed Utilization Efficiency (FUE), Feed Conversion Ratio (FCR), Protein Efficiency Ratio (PER), Relative Growth Rate (RGR), and Survival Rate (SR). The results showed that the use of chicken egg starch in artificial feed gave a real effect ( $p<0.05)$ on TFC, FUE, FCR, PER, and RGR, but no significant effect $(\mathrm{P} \geq 0,05)$ on SR. Treatment with the addition of $30 \%$ chicken meal (Treatment $\mathrm{C})$ had the best value for TFC at $146.87 \%$, the FUE of $88.77 \%$, the PER of $2.61 \%$ and the RGR of $7.65 \% /$ day than of the another treatments. Monitoring of water quality values on maintenance media has shown that at a reasonable range for the maintenance of catfish culture.

Keywords: Catfish Fed, Chicken Egss Rejects, Clarias gariepinus, Growth, Survival Rate

(C) Copyright by Saintek Perikanan (Indonesian Journal of Fisheries Science and Technology), ISSN : 1858-4748 


\section{PENDAHULUAN}

Lele dumbo (Clarias gariepinus) merupakan ikan konsumsi air tawar yang dikembangkan di Indonesia, selain itu juga dikenal memiliki rasa yang khas sehingga banyak digemari oleh masyarakat. Kebutuhan lele dumbo ( $C$. gariepinus) dari tahun ke tahun semakin meningkat, seiring dengan bertambahnya jumlah penduduk yang semakin meningkat, tetapi pencapaian produksi perikanan masih dibawah target hanya $82,36 \%$. Pencapaian yang belum memenuhi target ini diduga karena mahalnya harga pakan ikan dan sebagian besar komponen pakan masih impor sehingga keuntungan pembudidaya relatif kecil yang mengakibatkan menurunnya minat pembudidaya untuk memelihara lele dumbo (Trisnawati et al., 2014).

Pakan pada kegiatan budidaya umumnya adalah pakan komersial yang menghabiskan sekitar $60-70 \%$ dari total biaya produksi yang dikeluarkan (Arief et al., 2014). Kualitas suatu pakan ditentukan oleh komposisi bahan yang digunakan. Semakin banyak kandungan protein maka kualitas pakan tersebut semakin baik. Pakan yang dikonsumsi dapat menunjang pertumbuhan dan kelulushidupan, oleh karena itu pakan yang diberikan harus sesuai dengan kebutuhan ikan baik jumlah maupun kualitasnya (Trisnawati et al., 2014).

Bahan untuk pakan harus memenuhi kualitas dan kuantitas yang baik. Alternatif pemecahan yang dapat diupayakan adalah dengan membuat pakan buatan sendiri melalui teknik sederhana dengan memanfaatkan sumbersumber bahan baku yang relatif murah (Anggraeni dan Rahmiati, 2016). Telur merupakan salah satu hasil ternak yang berperan sebagai sumber protein hewani, mudah dicerna dan memiliki kandungan gizi lengkap. Telur ayam afkir merupakan salah satu limbah, tetapi memiliki protein tinggi sehingga dapat digunakan untuk bahan pakan. Tepung telur ayam afkir mengandung protein kasar sebesar $54.14 \%$, lemak kasar sebesar $22,44 \%$, serat kasar sebesar $5,85 \%$, abu sebesar $10,67 \%$ serta bahan ekstrak tanpa nitrogen (BETN) sebesar 6,90\% (Hasil Analisa Laboratorium Nutrisi dan Pakan Ternak, Fakultas Peternakan dan Pertanian, Universitas Diponegoro, 2017). Penelitian yang telah dilakukan oleh Yoel et al., (2016) pemberian tepung usus ayam sebagai pengganti tepung ikan pada pakan ikan lele dumbo (C. gariepinus) memberikan pengaruh nyata pada pertumbuhan mutlak ikan lele dumbo $(C$. gariepinus). Sampai saat ini belum ada penelitian penambahan tepung telur ayam afkir pada pakan buatan berprobiotik terhadap efisiensi pemanfaatan pakan, pertumbuhan dan kelulushidupan ikan lele dumbo (C. gariepinus). Sehigga perlu dilakukan penelitian lebih lanjut.

\section{METODE PENELITIAN}

Persiapan bahan pakan yaitu meliputi persiapan membuat tepung telur ayam afkir. Proses pembuatan tepung telur ayam afkir yaitu telur ayam afkir direbus kurang lebih 30 menit kemudian diblender menggunakan mesin. Setelah diblender dikeringkan dibawah sinar matahari. Telur ayam afkir yang sudah kering kemudian diblender hingga ukuran partikel lebih kecil kemudian disaring dengan saringan tepung. Bahan-bahan pakan lainnya yang digunakan dalam penelitian ini yaitu tepung ikan, tepung bungkil kedelai, tepung terigu, tepung dedak, tepung jagung, minyak ikan, minyak jagung, vit-min mix, dan CMC (lihat Tabel 1). Bahan tersebut disaring hingga memiliki ukuran yang homogen. Proses penentuan formulasi pakan dalam pembuatan pakan uji didasarkan dengan kebutuhan protein ikan lele dumbo yaitu $32 \%$.

Proses pembuatan pakan uji diawali dengan mencampur semua bahan pakan secara merata mulai dari bahan persentasenya paling kecil hingga besar, kemudian ditambah air hangat sedikit demi sedikit hingga kalis dan tidak lengket ditangan. Pakan digiling dengan pencetak pelet, kemudian dimasukkan ke dalam oven dengan suhu $40^{\circ} \mathrm{C}$ sampai kering.

Probiotik pakan yang digunakan mengandung jenis bakteri antara lain Lactobacillus casei, Saccharomyces cerevisiae, Bacillus subtilis, Bacillus lycheniformis, dan Lactobacillus plantarum. Kapadatan probiotik yang digunakan yaitu $10^{7} \mathrm{CFU} / \mathrm{ml}$. Penggunaan probiotik diawali dengan mengambil probiotik pakan sebanyak $2,5 \mathrm{ml}$, kemudian $5 \mathrm{ml}$ molase, $250 \mathrm{ml}$ akuades kemudian dicampur setelah homogen disemprotkan ke pakan. Pakan diinkubasi selama 48 jam. Pakan yang telah siap ditempatkan ke wadah. Pemberian pakan diberikan secara at satiation.

Ikan uji yang digunakan dalam penelitian ini adalah benih ikan lele dumbo ( $C$. gariepinus) berukuran $5-7 \mathrm{~cm}$ dengan rata-rata bobot awal $2.04 \pm 0.05 \mathrm{~g}$, berasal dari Balai Pembenihan Ikan Air Tawar Ngrajek, Jawa Tengah. Jumlah benih yang ditebar untuk tiap perlakuan dan ulangan sebanyak 1 ekor/ liter, sebelum dilakukan penelitian ikan uji di aklimatisasi terlebih dahulu selama 7 hari.

Metode penelitian yang digunakan adalah metode eksperimental. Menurut Srigandono (1992), metode eksperimen merupakan suatu usaha terencana untuk mengungkap fakta-fakta baru atau menguatkan teori bahkan membantah penelitian-penelitian yang sudah ada. Rancangan percobaan yang digunakan dalam penelitian ini adalah rancangan acak lengkap (RAL). Menurut Sudjana (1991) bahwa RAL digunakan pada penelitian yang bersifat homogen (perlakuan tunggal) dan perlakuan dikenakan sepenuhnya secara acak terhadap unit-unit eksperimen. Penelitian ini menggunakan 4 perlakuan dan setiap perlakuan diulang sebanyak 3 kali, susunan perlakuannya adalah sebagai berikut: Perlakuan A : pakan tanpa penambahan tepung telur ayam afkir Perlakuan B : pakan ditambahkan tepung telur ayam afkir $15 \%$ Perlakuan C : pakan ditambahkan tepung telur ayam afkir $30 \%$ Perlakuan D : pakan ditambahkan tepung telur ayam afkir $45 \%$ Penentuan perlakukan yang digunakan berdasarkan hasil penelitian pendahuluan

Pengumpulan data meliputi variabel pertumbuhan yaitu total konsumsi pakan (TKP), efisiensi pemanfaatan pakan (EPP), rasio konversi pakan (FCR), protein efisiensi rasio (PER), laju pertumbuhan relatif (RGR) dan kelulushidupan (SR). Variabel kualitas air yaitu DO, $\mathrm{pH}$, suhu, dan ammonia.

\section{Total Konsumsi Pakan}

Perhitungan nilai tingkat konsumsi pakan dihitung dengan menggunakan rumus Pereira et al., (2007) sebagai berikut :

$$
\mathrm{TKP}=\mathrm{F} 1-\mathrm{F} 2
$$

Dimana TKP yaitu Total konsumsi pakan (g), F1 yaitu jumlah pakan awal (g), F2 yaitu jumlah pakan akhir (g)

\section{Efisiensi Pemanfaatan Pakan}

Perhitungan nilai efisiensi pemanfaatan pakan (EPP) dihitung dengan menggunakan rumus Tacon (1987), sebagai berikut :

$$
\mathrm{EPP}=\frac{\mathrm{W}_{\mathrm{t}}-\mathrm{W}_{\mathrm{o}}}{\mathrm{F}} \times 100 \%
$$

\footnotetext{
(C) Copyright by Saintek Perikanan (Indonesian Journal of Fisheries Science and Technology), ISSN : 1858-4748
} 
Tabel 1. Komposisi dan Analisa Proksimat Pakan yang Digunakan Selama Penelitian (\% Bobot Kering)

\begin{tabular}{|c|c|c|c|c|c|}
\hline \multirow{2}{*}{ No } & \multirow{2}{*}{ Bahan Penyusun pakan } & \multicolumn{4}{|c|}{ Pakan (g) } \\
\hline & & A & B & $\mathrm{C}$ & $\mathrm{D}$ \\
\hline 1 & Tp. Telur Ayam Afkir & 0 & 15,00 & 30,00 & 45,00 \\
\hline 2 & Tp. Ikan & 36,00 & 26,15 & 11,45 & 5,50 \\
\hline 3 & Tp. Bkl. Kedelai & 36,00 & 25,65 & 19,15 & 4,70 \\
\hline 4 & Tp. Terigu & 9,00 & 8,55 & 14,35 & 8,70 \\
\hline 5 & Tp. Dedak & 7,00 & 10,15 & 8,00 & 20,00 \\
\hline 6 & Tp. Jagung & 2,40 & 5,50 & 8,05 & 7,50 \\
\hline 7 & Minyak Ikan & 2,00 & 2,00 & 2,00 & 2,00 \\
\hline 8 & Minyak Jagung & 1,00 & 1,00 & 1,00 & 1,00 \\
\hline 9 & Vit-Min Mix & 5,00 & 5,00 & 5,00 & 5,00 \\
\hline 10 & $\mathrm{CMC}$ & 1,00 & 1,00 & 1,00 & 1,00 \\
\hline & Total & 100,00 & 100,00 & 100,00 & 100,00 \\
\hline & Protein $(\%)$ & 32,00 & 32,00 & 32,00 & 32,00 \\
\hline & Lemak $(\%)$ & 7,85 & 10,31 & 11,96 & 15,26 \\
\hline & Energi (kkal/g)a & 257,23 & 274,13 & 296,65 & 308,83 \\
\hline & Rasio E/P (kkal/g P)b & 8,04 & 8,60 & 9,27 & 9,65 \\
\hline
\end{tabular}

* Berdasarkan perhitungan DE (digestable energy) dengan asumsi untuk protein = 3,5 kkal/g, lemak = 8,1 kkal/g, BETN = 2,5 kkal/g (Wilson, 1982).

** Menurut De Silva (1987), nilai E/P bagi pertumbuhan optimal ikan berkisar antara 8-12 kkal/g.Sumber: Laboratorium Ilmu Nutrisi dan Pakan, Fakultas Peternakan dan Pertanian, Universitas Diponegoro, Semarang (2017).

Dimana EPP yaitu Efisiensi pemanfaatan pakan (\%), Wt yaitu bobot total ikan pada akhir pemeliharaan $(\mathrm{g})$, Wo yaitu bobot total ikan pada awal pemeliharaan (g), F yaitu jumlah pakan yang dikonsumsi selama penelitian $(\mathrm{g})$

\section{Rasio Konversi Pakan (FCR)}

Perhitungan nilai rasio konversi pakan (FCR) dihitung dengan menggunakan rumus Effendi (1997), sebagai berikut :

$$
\mathrm{FCR}=\frac{\mathrm{F}}{(\mathrm{Wt}+\mathrm{d})-\mathrm{W} 0}
$$

Dimana FCR yaitu rasio konversi pakan, $F$ yaitu jumlah pakan yang diberikan selama penelitian (g), Wt yaitu bobot total ikan pada akhir penelitian (g), W0 yaitu bobot total ikan pada awal penelitian (g), D yaitu bobot ikan yang mati selama penelitian $(\mathrm{g})$.

\section{Protein Efisiensi Rasio (PER)}

Perhitungan nilai protein efisiensi rasio (PER) dengan menggunakan rumus Tacon (1987), sebagai berikut :

$$
\mathrm{PER}=\frac{\mathrm{W}_{\mathrm{t}}-\mathrm{W}_{\mathrm{o}}}{\mathrm{Pi}} \times 100 \%
$$

Dimana PER yaitu Protein efisiensi rasio (\%),Wt yaitu bobot total ikan pada akhir pemeliharaan (g), Wo yaitu bobot total ikan pada awal pemeliharaan $(\mathrm{g})$, Pi yaitu berat pakan yang dikonsumsi $\mathrm{x} \%$ protein pakan.

\section{Laju Pertumbuhan Relatif (RGR)}

Menurut Takeuchi (1988), laju pertumbuhan relatif atau relative growth rate (RGR) ikan dihitung menggunakan rumus sebagai berikut:

$$
\mathrm{RGR}=\frac{\mathrm{W}_{\mathrm{t}}-\mathrm{W}_{\mathrm{o}}}{\mathrm{W}_{\mathrm{o}} \times \mathrm{t}} \mathrm{x}
$$

Dimana RGR yaitu Laju pertumbuhan relatif (\% per hari), $\mathrm{W}_{\mathrm{t}}$ yaitu bobot total ikan pada akhir pemeliharaan $(\mathrm{g}), \mathrm{W}_{\mathrm{o}}$ yaitu bobot total ikan pada awal pemeliharaan $(\mathrm{g}), \mathrm{t}$ yaitu waktu pemeliharaan (hari)

\section{Kelulushidupan}

Kelulushidupan atau survival rate (SR) dihitung untuk mengetahui tingkat kematian kematian ikan uji selama penelitian, kelulushidupan dapat dihitung berdasarkan rumus Effendi (1997):

$$
\mathrm{SR}=\frac{\mathrm{N}_{\mathrm{t}}}{\mathrm{N}_{0}} \times 100 \%
$$

Dimana SR yaitu Tingkat kelulushidupan ikan (\%), $\mathrm{N}_{\mathrm{t}}$ yaitu jumlah ikan pada akhir penelitian (ekor), $\mathrm{N}_{0}$ yaitu jumlah ikan pada awal penelitian (ekor)

\section{Parameter Kualitas Air}

Parameter data kualitas air yang diukur meliputi DO, $\mathrm{pH}$ suhu, amonia. DO diukur dengan menggunakan DO meter, $\mathrm{pH}$ diukur dengan $\mathrm{pH}$ meter, suhu diukur dengan termometer dan untuk pengukuran amonia, sampel air diukur di laboratorium teknik lingkungan, UNDIP.

\section{Analisis Data}

Analisa data meliputi tingkat konsumsi pakan (TKP), efisiensi pemanfaatan pakan (EPP), rasio konversi pakan (FCR), Protein Efficiency Ratio (PER), laju pertumbuhan spesifik (SGR), kelulushidupan (SR) dan kualitas air. Variabel yang didapatkan kemudian dianalisis menggunakan analisis sidik ragam (ANOVA) selang kepercayaan 95\%, sebelum dilakukan ANOVA, data terlebih dahulu dilakukan uji normalitas, uji homogenitas, dan uji addivitas guna mengetahui bahwa data bersifat normal, homogen dan aditif untuk dilakukan uji lebih lanjut yaitu analisis sidik ragam. Data kualitas air dianalisis secara deskriptif. 


\section{HASIL DAN PEMBAHASAN}

\section{Hasil}

Hasil penelitian pemanfaatan tepung telur ayam afkir pakan buatan terhadap pemanfaatan pakan meliputi nilai TKP; EPP; FCR; PER; RGR; dan SR tersaji pada Tabel 2. Sesuai hasil yang terdapat pada tabel diketahui nilai total konsumsi pakan (TKP) pada masing - masing perlakuan yang tertinggi hingga terendah adalah perlakuan $C 146,87 \pm 2,66 \mathrm{~g}$, perlakuan

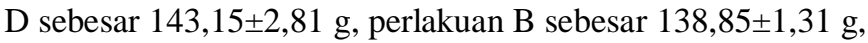

dan perlakuan A sebesar $133,48 \pm 2,70$ g. Nilai efisiensi pemanfaatan pakan (EPP) pada masing-masing perlakuan dari yang tertinggi hingga terendah adalah perlakuan $\mathrm{C}$ sebesar $88,77 \pm 2,21 \%$, perlakuan D sebesar $81,90 \pm 2,27 \%$, perlakuan B sebesar $78,77 \pm 0,62 \%$, dan perlakuan A sebesar 74,44 $\pm 5,02 \%$. Nilai rasio konversi pakan (FCR) pada masing-masing perlakuan yang tertinggi hingga terendah adalah perlakauan $\mathrm{A}$ $1,29 \pm 0,05$, perlakuan B sebesar $1,20 \pm 0,02$, perlakuan $C$ sebesar $1,16 \pm 0,02$, perlakuan D sebesar 1,09 $\pm 0,02$.

Tabel 2. Nilai Rata-rata EPP, RGR, dan SR selama Pemeliharaan

\begin{tabular}{ccccccc} 
Perlakuan & \multicolumn{5}{c}{ Variabel yang diamati } \\
\cline { 2 - 7 } & TKP $(\mathrm{g})$ & EPP $(\%)$ & FCR & PER $(\%)$ & RGR $(\% /$ hari $)$ & SR $(\%)$ \\
\hline A & $133,48 \pm 2,70^{\mathrm{c}}$ & $74.44 \pm 5.02^{\mathrm{c}}$ & $1,29 \pm 0,05^{\mathrm{a}}$ & $2,38 \pm 0.16^{\mathrm{c}}$ & $5,86 \pm 0.47^{\mathrm{c}}$ & $95,00 \pm 5.00^{\mathrm{a}}$ \\
B & $138,85 \pm 1,31^{\mathrm{b}}$ & $78,77 \pm 0,62^{\mathrm{bc}}$ & $1,20 \pm 0,02^{\mathrm{bc}}$ & $2,39 \pm 0.02^{\mathrm{bc}}$ & $6,33 \pm 0.19^{\mathrm{bc}}$ & $93,33 \pm 2.89^{\mathrm{a}}$ \\
C & $146,87 \pm 2,66^{\mathrm{a}}$ & $88,77 \pm 2.21^{\mathrm{a}}$ & $1,16 \pm 0,02^{\mathrm{c}}$ & $2,61 \pm 0.07^{\mathrm{a}}$ & $7,65 \pm 0.38^{\mathrm{a}}$ & $95,00 \pm 5.00^{\mathrm{a}}$ \\
D & $143,15 \pm 2,81^{\mathrm{ab}}$ & $81,90 \pm 2.27^{\mathrm{b}}$ & $1,09 \pm 0,02^{\mathrm{d}}$ & $2,48 \pm 0.07^{\mathrm{ab}}$ & $6,80 \pm 0.47^{\mathrm{b}}$ & $88,33 \pm 2.89^{\mathrm{a}}$ \\
\hline
\end{tabular}

Ket : Nilai rerata dengan huruf superscript yang berbeda menunjukkan adanya perbedaan yang nyata $(\mathrm{P}<0,05)$ dan huruf superscript yang sama menunjukkan tidak berbeda nyata.

Nilai rata-rata rasio efisiensi protein (PER) pada masingmasing perlakuan dari yang tertinggi hingga terendah adalah

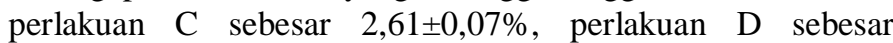
$2,48 \pm 0,07 \%$, perlakuan B sebesar $3,39 \pm 0,02 \%$, dan perlakuan A sebesar $2,38 \pm 0,16 \%$. Nilai rata-rata laju pertumbuhan relatif (RGR) pada masing-masing perlakuan dari yang tertinggi hingga terendah adalah perlakuan $\mathrm{C}$ sebesar 7,65 $\pm 0,38 \%$ /hari, perlakuan D sebesar 6,80 $\pm 0,47 \%$ /hari, perlakuan B sebesar $6,33 \pm 0,19 \%$ /hari, dan perlakuan A sebesar 5,86 $\pm 0,47 \%$ /hari. Nilai rata-rata kelulushidupan (SR) pada masing-masing perlakuan dari yang tertinggi hingga terendah adalah perlakuan A dan C sebesar 95,00 $\pm 5,00 \%$, perlakuan B sebesar 93,33 $\pm 2,89$ dan perlakuan D yaitu sebesar $88,33 \pm 2,89 \%$

Berdasarkan data efisiensi pemanfaatan pakan, laju pertumbuhan relatif dan kelulushidupan pada ikan lele dumbo (C. gariepinus) selama pemeiharaan dapat dibuat histogram pada Gambar 1, 2, dan 3.

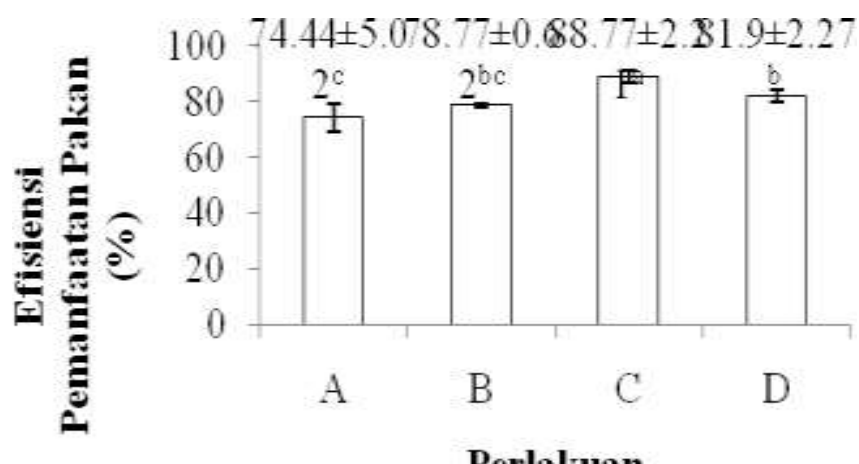

Perlakuan

Gambar 1. Nilai Efisiensi Pemanfaatan Pakan Ikan Lele Dumbo (C. gariepinus) pada Percobaa Penambahan Tepung Telur Ayam Afkir pada Pakan Buatan

Ket : Angka dengan huruf superskrip berbeda menunjukkan adanya perbedaan yang nyata $(p<0.05)$

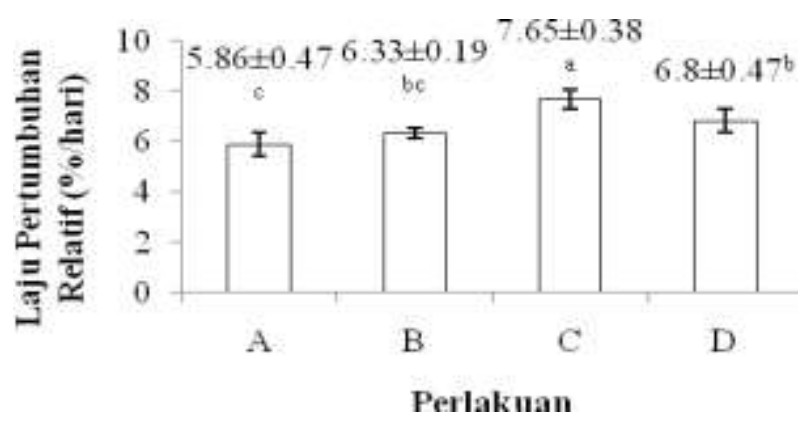

Gambar 2. Nilai Laju Pertumbuhan Relatif Ikan Lele Dumbo (C. gariepinus) pada Percobaa Penambahan Tepung Telur Ayam Afkir pada Pakan Buatan

Ket : Angka dengan huruf superskrip berbeda menunjukkan adanya perbedaan yang nyata $(p<0.05)$

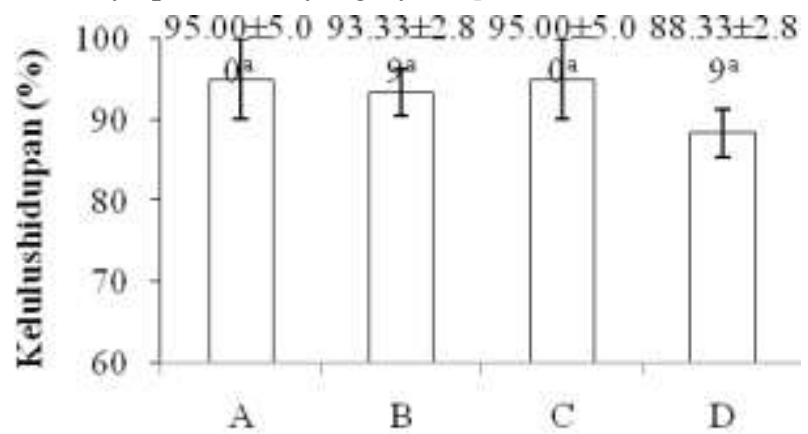

Perlakuan

Gambar 3. Nilai Kelulushidupan Ikan Lele Dumbo (C. gariepinus) pada Percobaa Penambahan Tepung Telur Ayam Afkir pada Pakan Buatan

Ket : Angka dengan huruf superskrip yang sama menunjukkan tidak adanya perbedaan yang nyata $(p>0.05)$

() Copyright by Saintek Perikanan (Indonesian Journal of Fisheries Science and Technology), ISSN : 1858-4748 
Hasil pengukuran parameter kualitas air pada media ikan lele dumbo ( $C$. gariepinus) selama pemeliharaan tersaji pada Tabel 3. Kualitas air pada media pemeliharaan ikan lele dumbo dumbo (C. gariepinus) pada penelitian ini telah memenuhi kebutuhan hidup ikan lele dumbo. Kualitas air dalam penelitian ini dapat dikatakan layak berdasarkan pustaka tentang kondisi kualitas air yang optimal bagi kehidupan ikan lele dumbo $(C$. gariepinus).

Tabel 3. Hasil Pengukuran Parameter Kualitas Air selama Pemeliharaan

\begin{tabular}{ccc}
\hline $\begin{array}{c}\text { Parameter } \\
\text { Kualitas Air }\end{array}$ & $\begin{array}{c}\text { Kisaran Nilai } \\
\text { Parameter Kualitas Air }\end{array}$ & $\begin{array}{c}\text { Pustaka } \\
(\text { Kelayakan })\end{array}$ \\
\hline Suhu $\left({ }^{0} \mathrm{C}\right)$ & $24-30$ & $22-32^{\mathrm{a}}$ \\
$\mathrm{DO}(\mathrm{mg} / \mathrm{l})$ & $3,3-6,5$ & $>3 \mathrm{mg} / \mathrm{l}^{\mathrm{a}}$ \\
$\mathrm{pH}$ & $6,8-7,1$ & $6,5-8,6^{\mathrm{b}}$ \\
$\mathrm{NH}_{3}(\mathrm{mg} / \mathrm{l})$ & $0-0,31$ & $<1^{\mathrm{a}}$ \\
\hline
\end{tabular}

Keterangan: ${ }^{\mathrm{a}} \mathrm{SNI}$ (2015), ${ }^{\mathrm{b}}$ Ahmadi et al., (2012)

\section{Pembahasan}

Pemanfaatan pakan buatan pada ikan lele dumbo ( $C$. gariepinus) yang diamati yaitu meliputi total konsumsi pakan (TKP), rasio konversi pakan (FCR), efisiensi pemanfaatan pakan (EPP), dan protein efisiensi rasio (PER). Hasil penelitian yang dilakukan nilai Total konsumsi pakan tertinggi yaitu pada perlakuan C sebesar 146,87 $\pm 2,66 \mathrm{~g}$ dan yang terendah terdapat pada perlakuan A sebesar 133,48 $\pm 2,70$ g. Total konsumsi tertinggi pada perlakuan $\mathrm{C}$ hal ini diduga karena pemberian pakan dengan sifat fisik pada perlakuan ini lebih disukai daripada perlakuan lain sehingga mempengaruhi jumlah pakan yang dikonsum. Pakan yang dikonsumsi oleh ikan bisa berbeda beda Menurut Abidin et al., (2015), besar kecilnya total konsumsi pakan pada ikan dipengaruhi oleh beberapa faktor, antara lain sifat fisik pakan misalnya bau, rasa, ukuran, dan warna. Faktor lain yang berpengaruh seperti kualitas air misalnya suhu pada suatu perairan. Perairan yang memiliki suhu tinggi akan mempengaruhi proses metabolisme ikan, semakin tinggi suhu akan menyebabkan ikan cenderung mengkonsumi pakan lebih banyak atau proses metabolisme dari ikan akan meningkat.

Kandungan nutrisi yang terkandung pada pakan dapat meningkatkan tingkat konsumsi pakan ikan lele dumbo. Pakan yang mengandung nutrisi yang cukup baik diduga dapat meningkatkan palatabilitas pakan dan tingkat pengambilan pakan oleh ikan. Tingkat konsumsi pakan yang lebih tinggi akan cenderung menghasilkan pertumbuhan yang lebih tinggi dibandingkan jika tingkat konsumsi pakannya lebih sedikit. Menurut Amin (2007), tingkat konsumsi pakan yang lebih tinggi akan cenderung menghasilkan pertumbuhan yang lebih tinggi dibandingkan jika tingkat konsumsi pakannya lebih sedikit. Rendahnya tingkat konsumsi pakan menyebabkan semakin rendahnya kemungkinan ikan untuk memenuhi kebutuhan nutriennya, sehingga mengakibatkan rendahnya pertumbuhan.

Hasil penelitian yang dilakukan menunjukkan bahwa nilai efisiensi pemanfaatan pakan dengan penambahan tepung telur ayam afkir pada pakan buatan didapatkan nilai tertinggi pada perlakuan $\mathrm{C}$ sebesar $88,77 \pm 2,22$, selanjutnya pada perlakuan $\mathrm{D}$

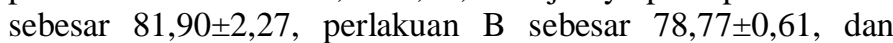
terendah perlakuan A sebesar 74,44 $\pm 5,02$. Berdasarkan nilai
EPP pada setiap perlakuan dalam penelitian ini dinyatakan baik karena memiliki nilai EPP di atas 50\%. Nilai efisiensi pemanfaatan pakan yang tinggi dipengaruhi oleh nilai total konsumsi pakan yang tinggi pada setiap perlakuan. Hal ini diduga bahwa tepung telur ayam afkir mengandung protein yang cukup tinggi sehingga dapat memenuhi kebutuhan nutrisi yang dibutuhkan ikan lele dumbo. Sesuai dengan pernyataan Trisnawati et al., (2014) semakin tinggi kandungan protein yang terdapat dalam pakan akan meningkatkan daya cerna ikan terhadap pakan. Hal ini diperkuat dengan pendapat Amalia et al., (2013), peningkatan nilai efisiensi pemanfaatan pakan menunjukkan bahwa pakan yang dikonsumsi memiliki kualitas yang baik, sehingga dapat dimanfaatkan secara efisien.

Nilai efisiensi pemanfaatan pakan yang tinggi menunjukkan bahwa penggunaan pakan lebih efisien pada ikan yang diberi tepung telur ayam afkir. Efisiensi pakan yang tinggi menunjukkan penggunaan dan pemanfaatan pakan yang efisien, sehingga hanya sedikit protein yang dirombak untuk memenuhi kebutuhan energi dan selebihnya digunakan untuk pertumbuhan. Menurut Marzuqi et al., (2012) menyatakan bahwa semakin tinggi kadar protein pakan, jumlah pakan yang dikonsumsi juga cenderung semakin tinggi. Nilai efisiensi pakan yang rendah menunjukkan bahwa ikan memerlukan pakan dengan jumlah yang lebih banyak untuk dapat meningkatkan beratnya. Selain itu tidak semua makanan yang dimakan oleh ikan digunakan untuk pertumbuhan. Sebagian besar energi dari makanan digunakan untuk pemeliharaan, sisanya untuk aktivitas, pertumbuhan dan reproduksi.

Pakan yang baik harus mengandung nutrisi yang lengkap. Kandungan nutrisi tersebut berfungsi untuk kelangsungan hidup. Pemberian bakteri probiotik melalui pakan dilakukan bertujuan agar dapat mendegradasi protein, lemak maupun karbohidrat dalam tubuh lele. Menurut Setiawati (2013) pemberian bakteri dalam pakan juga diharapkan dapat masuk dalam saluran pencernaan ikan sehingga dapat memperbaiki kemampuan ikan dalam mencerna pakan. Menurut Ibbaren et al., (2012) penggunaan bakteri probiotik merupakan salah satu solusi internal untuk menghasilkan pertumbuhan dan efisiensi pakan yang optimal, mengurangi biaya produksi sehingga pada akhirnya dapat mengurangi beban lingkungan karena akumulasi limbah di media pemeliharaan

Nilai rasio konversi pakan dengan penambahan tepung telur ayam afkir pada pakan buatan didapatkan nilai tertinggi pada perlakuan A $1,29 \pm 0,05$ dan nilai terendah pada perlakuan C yaitu $1,09 \pm 0,02$. Perlakuan $\mathrm{C}$ menghasilkan pertumbuhan serta efisiensi pakan yang tinggi sehingga nilai rasio konversi pakannya rendah. Besar kecilnya nilai konversi pakan merupakan gambaran tingkat efisiensi pakan yang diberikan.

Menurut Ardita et al., (2015) semakin rendah nilai FCR menunjukkan bahwa semakin efisien pakan dan pakan yang dimakan digunakan dengan baik oleh ikan untuk pertumbuhan. Menurut Fran dan Junius, (2013) nilai konversi pakan sebenarnya bukan merupakan angka mutlak, karena tidak hanya ditentukan oleh kualitas pakan, akan tetapi dipengaruhi pula oleh faktor-faktor lain seperti jenis ikan dan ukuran ikan, jumlah padat tebar, kualitas air, dan faktor genetic. Menurut Marimuthu et al., (2010) frekuensi makan sangat penting karena dapat mempengaruhi pertumbuhan ikan secara maksimal. Tergantung pada ukuran ikan, umur dan kondisi kultur. Termasuk suhu air, kualitas makanan dan jumlah dari makanan yang disediakan. 
Protein efisiensi rasio merupakan nilai yang menunjukkan jumlah bobot ikan yang dihasilkan dari tiap unit berat protein dalam pakan dengan asumsi bahwa semua protein digunakan untuk pertumbuhan. Berdasarkan hasil penelitian, nilai PER yang tertinggi adalah perlakuan $C$ sebesar $2,61 \pm 0,06 \%$ dan terendah adalah perlakuan A sebesar 2,38 $\pm 0,16 \%$. Perbedaan nilai efisiensi protein pada setiap perlakuan diduga disebabkan oleh kandungan energi dan kadar protein yang ada pada pakan. Perlakuan $\mathrm{C}$ merupakan hasil tertinggi pada protein rasio karena pada perlakuan $\mathrm{C}$ mengandung protein 33,95\% yang mana dapat mencukupi kebutuhan protein ikan lele untuk tumbuh. Menurut SNI (2006), menyatakan bahwa kadar minimal protein yaitu sebesar $30 \%$. Menurut Rahmawan et al., (2014), menyatakan nilai PER dipengaruhi oleh kadar protein dan komponen lain dalam bahan makanan. Keseimbangan protein penting dalam formulasi pakan karena berperan besar dalam pertumbuhan, serta ketahanan tubuh ikan.

Pakan pada perlakuan A memberikan performa ikan lele dumbo yang lebih rendah dibandingkan dengan perlakuan lain. Hal ini diduga karena pakan A tidak ditambahkan tepung telur ayam afkir. Sehingga kandungan protein dalam pakan lebih rendah setelah dilakukan uji proksimat. Penelitian yang dilakukan Hanief et al., (2014) menunjukkan bahwa perbedaan komposisi campuran dalam formulasi pakan mempengaruhi nilai rasio efisiensi protein, dimana seiring dengan meningkatnya kadar protein pada formulasi pakan akan meningkatkan nilai rasio efisiensi protein pada ikan.

Ketersediaan pakan dengan kualitas dan kuantitas nutrisi yang sesuai dengan kebutuhan ikan sangat diperlukan terhadap pertumbuhan ikan. Kebutuhan nutrisi ikan terutama protein yang sesuai dengan sifat dan kebiasaan makan dapat meningkatkan efisiensi pakan. Menurut Soedibya (2013), kualitas dan kuantitas protein yang diberikan akan mempengaruhi retensi protein tubuh dan selanjutnya ke pertumbuhan ikan. Apabila protein dalam pakan kurang mengakibatkan pertumbuhan ikan menjadi lambat, sehingga protein dalam jaringan tubuh akan dimanfaatkan untuk mempertahankan fungsi jaringan tubuh yang lebih penting.

Berdasarkan hasil pengamatan laju pertumbuhan relatif menunjukkan bahwa perlakuan dengan pemanfaatan tepung telur ayam afkir pada pakan buatan dengan dosis masingmasing $(0 \%, 15 \%, 30 \%$, dan $45 \%)$ memberikan pengaruh nyata $(\mathrm{P}<0,05)$ terhadap laju pertumbuhan relatif ikan lele dumbo. Nilai RGR tertinggi didapat pada perlakuan $C$ sebesar $7,65 \pm 0,38$ dan terendah pada perlakuan A sebesar 5.86 \pm 0.47 . Pemanfaatan tepung telur ayam afkir diduga dapat meningkatkan nilai RGR pada ikan lele dumbo. Peningkatan pertumbuhan ikan lele dumbo diduga karena adanya kandungan asam amino pada tepung telur ayam afkir. Menurut Zaheer (2015), telur ayam mengandung 9 jenis asam amino yaitu histidine, isoleusin, leusin, lisin, metionin, fenilalanin, treonin, triptofan dan valin. Kualitas protein, ukuran dan efisiensi penggunaan protein yang dikonsumsi ditentukan oleh proporsi asam-asam amino protein. Menurut Giri et al., (2009) menyatakan keseimbangan komposisi asam amino dalam pakan sangat menentukan efektivitas penggunaan protein pakan untuk pertumbuhan ikan.

Laju pertumbuhan berhubungan dengan pertambahan bobot tubuh ikan yang dihasilkan dari pemanfaatan nutrisi dalam pakan. Tingkat pertumbuhan ikan lele dumbo mengalami peningkatan dikarenakan kebutuhan protein, lemak dan karbohidrat sudah mencukupi dan sesuai dengan kebutuhan ikan untuk melakukan pertumbuhan. Menurut
Anggraeni dan Rahmiati (2016) menyatakan tinggi rendahnya kandungan protein optimum dalam pakan dipengaruhi oleh lemak dan karbohidrat yang cukup. Tanpa karbohidrat dan lemak yang cukup ikan menggantungkan energinya sebagian besar dari protein pakan, yang akan digunakan sebagai sumber energi untuk mencerna makanan dan proses metabolisme. Menurut Ariati (2013), keseimbangan yang tepat antara energi dan protein pakan sebagian besar dipenuhi oleh nutrien nonprotein seperti lemak dan karbohidrat. Apabila energi yang berasal dari sumber non-protein cukup maka sebagian besar protein akan dimanfaatkan untuk tumbuh, namun apabila energi dari non-protein tidak terpenuhi maka protein akan digunakan sebagai sumber energi sehingga fungsi protein sebagai pembangun tubuh akan berkurang

Hasil Analisis ragam menunjukkan bahwa pemanfaatan tepung telur ayam afkir pada pakan buatan memiliki pengaruh tidak nyata $(\mathrm{P}>0,05)$ terhadap kelulushidupan ikan lele $(C$. gariepinus). hal ini diduga bahwa pakan dengan pemanfaatan tepung telur ayam afkir pada pakan buatan memberikan pengaruh pada pertumbuhan, akan tetapi tidak memberikan pengaruh nyata terhadap tingkat kelulushidupan. Nilai tingkat kelulushidupan tertinggi adalah perlakuan $\mathrm{A}$ dan perlakuan $\mathrm{C}$ sebesar $95,00 \pm 5,00 \%$. Adapun nilai terendah adalah perlakuan D sebesar $88.33 \pm 2.89 \%$. Tingkat kelulushidupan yang rendah diduga akibat penanganan selama penelitian kurang baik ditandai dengan hilangnya nafsu makan, ikan berenang upnormal dan lesu sehingga lama kelamaan ikan lele akan mati. Menurut Fitria (2012), tingkat kelangsungan hidup sangat dipengaruhi oleh kualitas air terutama suhu dan kandungan oksigen. Suhu merupakan salah satu faktor yang mempengaruhi pertumbuhan. Suhu dapat mempengaruhi aktifitas ikan, seperti pernafasan dan reproduksi. Suhu air sangat berkaitan dengan konsentrasi oksigen terlarut dan laju konsumsi oksigen ikan faktor

Tingkat kelulushidupan yang baik dipengaruhi oleh kondisi lingkungan yang optimal. Kondisi lingkungan yang baik dapat memungkinkan ikan tumbuh dengan baik. Menurut Trisnawati et al., (2014) yang dapat mempengaruhi tinggi rendahnya kelulushidupan suatu organisme adalah faktor biotik dan abiotik. Faktor biotik antara lain kompetitor, kepadatan populasi, umur dan kemampuan organisme dengan lingkungan sedangkan faktor abiotik seperti suhu, oksigen terlarut, $\mathrm{pH}$ dan kandungan ammonia

\section{Kualitas Air}

Berdasarkan kualitas air yang telah diamati selama pemeliharaan ikan nila selama 42 hari, diperoleh hasil suhu yang relatif fluktuatif. Suhu wadah selama pemeliharaan berkisar $25-30^{\circ} \mathrm{C}$. Suhu tersebut cukup sesuai dengan kondisi ikan lele. Menurut SNI (2015) kisaran suhu untuk ikan lele (Clarias sp) antara $22-32{ }^{\circ} \mathrm{C}$. Sesuai pendapat Madinawati et al., (2011) bahwa suhu air berpengaruh terhadap pertumbuhan dan perkembangan ikan. Ikan lele dumbo dapat hidup pada suhu air berkisar antara $20-30^{\circ} \mathrm{C}$ Suhu air yang sesuai akan meningkatkan aktivitas makan ikan, sehingga menjadikan ikan lele dumbo cepat tumbuh.

Oksigen terlarut yang diukur selama penelitian menunjukan hasil 3,00-4,8 $\mathrm{mg} / \mathrm{L}$. Hasil pengamatan dari variabel oksigen terlarut tersebut masih sesuai untuk budidaya ikan lele. Menurut SNI (2015) kebutuhan oksigen minimal 3 mg/L. Menurut Rachmawati et al., (2015) konsentrasi oksigen yang baik untuk ikan lele tidak boleh kurang dari $3 \mathrm{mg} / \mathrm{l}$. Oksigen yang rendah umumnya diikuti dengan meningkatnya

(c) Copyright by Saintek Perikanan (Indonesian Journal of Fisheries Science and Technology), ISSN : 1858-4748 
amoniak dan karbondioksida di air yang menyebabkan proses nitrifikasi menjadi terhambat sehingga mengganggu kelulushidupan ikan.

Parameter kualitas air yang menunjukan nilai keasaman dalam air yaitu $\mathrm{pH}$. Nilai $\mathrm{pH}$ yang diperoleh pada saat penelitian yaitu $6,8-7,1$ hasil dari variabel tersebut masih dalam batas kelayakan. Menurut Ahmadi et al., (2012) $\mathrm{pH}$ produktif perairain bagi pertumbuhan benih lele sangkuriang antara 6,5-8,6.

Nilai ammonia yang diperoleh selama penelitian yaitu 0 0,31 mg/L, kandungan tersebut masih dalam batas kewajaran. Menurut Hastuti dan Subandiyono (2014), kandungan ammonia dalam budidaya ikan lele system bioflok selama penelitian adalah berkisar 0,26 - 3,23 mg/L. Konsentrasi ammonia yang baik untuk pertumbuhan dan perkembangan ikan lele yaitu maksimal 0,1 mg/L.

\section{KESIMPULAN}

Kesimpulan yang dapat diambil dari hasil penelitian adalah sebagai berikut :

1. Penambahan tepung telur ayam afkir sebagai pakan yang berprobiotik pengaruh nyata terhadap efisiensi pemanfaatan pakan (EPP), dan laju pertumbuhan relatif (RGR) namun tidak memberikan pengaruh yang nyata terhadap kelulushidupan (SR) ikan lele dumbo (Clarias gariepinus).

2. Dosis terbaik dari pemberian tepung telur ayam afkir pada pembuatan pakan ikan lele dumbo (Clarias gariepinus) yaitu $30 \%$

\section{UCAPAN TERIMA KASIH}

Terima kasih penulis ucapkan kepada kepala Balai Benih Ikan Mijen, Kota Semarang yang telah menyediakan tempat dan fasilitas untuk pelaksanaan penelitian ini dan semua pihak yang telah membantu kelancaran penelitian ini.

\section{DAFTAR PUSTAKA}

Abidin, Z., M. Junaidi, Paryono, N. Cokrowati dan S. Yuniarti. 2015. Pertumbuhan dan Konsumsi Pakan Ikan Lele (Clarias sp.) yang Diberi Pakan Berbahan Baku Lokal. J. Depik. 4(1): 33-39.

Ahmadi, H., Iskandar., N. Kurniawati. 2012. Pemberian Probiotik dalam Pakan Terhadap Pertumbuhan Lele Sangkuriang (Clarias gariepinus) pada Pendederan II. J. Perikanan dan Kelautan. 3(4): 99-107.

Amalia, R., Subandiyono dan E. Arini. 2013. Pengaruh Penggunaan Papain terhadap Tingkat Pemanfaatan Protein Pakan dan Pertumbuhan Lele Dumbo (Clarias gariepinus). Jurnal of Aquaculture Management and Technology. 2 (1): 136-143.

Amin, M. 2007. Pengaruh Enzim Fitase dalam Pakan Terhadap Kecernaan Nutrien dan Kinerja Pertumbuhan Ikan Lele Dumbo (Clarias sp.). [Thesis]. Sekolah Pascasarjana, Institut Pertanian Bogor, Bogor, 56 hlm.
Anggraeni, D. N dan Rahmiati. 2016. Pemanfaatan Ampas Tahu Sebagai Pakan Ikan Lele (Clarias batrachus) Organik. Biogenesis. 4(1): 53-57.

Ardita, N., A. Budiharjo dan S. L. A. Sari. 2015. Pertumbuhan dan Rasio Konversi Pakan Ikan Nila (Oreochromnis niloticus) dengan Penambahan Prebiotik. Bioteknologi. 12(1): 16-21.

Ariati, R. 2013. Pengaruh Pemberian Tepung Kepala Udang Terhadap Laju Pertumbuhan dan Konversi Pakan Benih Lele Sangkuriang (Clarias Gariepinus). [Skripsi].Universitas Padjajaran. $25 \mathrm{hlm}$.

Arief, M., N. Fitriani dan S. Subekti. 2014. Pengaruh Pemberian Probiotik berbeda pada Pakan Komersil Terhadap Pertumbuhan dan Efisiensi Pakan Ikan Lele Sangkuriang (Clarias sp.). J. Ilmiah Perikanan dan Kelautan. 6(1): 49-53

De Silva, S.S. 1987. Finfish Nutritional Research in Asia. Proceeding of The Second Asian Fish Nutrition Network Meeting. Heinemann, Singapore. 128 p.

Effendie, M.I. 1997. Biologi Perikanan. Yayasan Pustaka Nusantara, Yogyakarta, $163 \mathrm{Hlm}$

Fitria, A.S. 2012. Analisis Kelulushidupan dan Pertumbuhan Benih Ikan Nila Larasati (Oreochromis niloticus) F5 D30-D70 pada Berbagai Salinitas. Fakultas Perikanan dan Ilmu Kelautan, Universitas Diponegoro. J. of Aquaculture Management and Technology. 1(1): 1834.

Fran, S. dan J. Akbar. 2013. Pengaruh Perbedaan Tingkat Protein dan Rasio Protein Pakan terhadap Pertumbuhan Ikan Sepat (Trichogaster pectoralis). Fish Scientiae. 3(5): 53-63.

Giri, I. N. A., A. S. Sentika., K. Suwirya dan M. Marzuqi. 2009. Kandungan Asam Amino Lisin Optimal Dalam Pakan Untuk Pertumbuhan Benih Ikan Kerapu Sunu Plectropomus leopardus. J. Ris. Akuakultur. 4(3): 357-366.

Hanief, M. A. R., Subandiyono dan Pinandoyo. 2014. Pengaruh Frekuensi Pemberian Pakan terhadap Pertumbuhan dan Kelulushidupan Benih Tawes (Puntius javanicus). J. of Aquaculture Management and Technology. 3(4): 67-74.

Hastuti, S dan Subandiyono. 2014. Performa Produksi Ikan Lele Dumbo (Clarias gariepinus) yang Dipelihara dengan Teknologi Biofloc. J. Of Fisheries Science and Technology (IJFST). 10(1): $37-42$.

Hidayat, D., A. D. Sasanti dan Yulisman. 2013. Kelangsungan Hidup, Pertumbuhan dan Efisiensi Pakan Ikan Gabus (Channa striata) Yang Diberi Pakan Berbahan Baku Tepung Keong Mas (Pomacea sp). J. Akuakultur Rawa Indonesia. 1(2): 161-172.

() Copyright by Saintek Perikanan (Indonesian Journal of Fisheries Science and Technology), ISSN : 1858-4748 
Irribaren, D., P. Daga. and M. T. Moreira., G. Feijoo. 2012. Potential Environmental Effects of Probiotics Used in Aquaculture. Aquacult Int 20:779-789

Madinawati, N. Serdiati dan Yoel. 2011. Pemberian Pakan Yang Berbeda Terhadap Pertumbuhan Dan Kelangsungan Hidup Benih Ikan Lele Dumbo (Clarias gariepinus). Media Litbang Sulteng., 4(2): 83-87.

Marimuthu, K. A. C. Cheen, S. Muralikrishnan, dan D. Kumar. 2010. Effect of Different Frequency on the Growth and Survival of African Catfish (Clarias gariepinus) Fingerlings. Advances in Environmental Biology. 4(2): 187-193.

Marzuqi, M., N. W. W. Astuti dan K. Suwirya. 2012. Pengaruh Kadar Protein dan Rasio Pemberian Pakan terhadap Pertumbuhan Ikan Kerapu Macan (Epinephelus fuscoguttatus). J. ilmu dan Teknologi Kelautan Tropis. 4(1): 55-65.

Pereira, L., T. Riquelme and H. Hosokawa. 2007. Effect of There Photoperiod Regimes on the Growth and Mortality of the Japanese Abalone (Haliotis discus hanaino). [Skripsi]. Kochi University, Aquaculture Department, Laboratory of Fish Nutrition, Japan, 26: 763-767 p.

Rachmawati, D., I. Samidjan dan H. Setyono. 2015. Manajemen Kualitas Air Media Budidaya Ikan Lele Sangkuriang (Clarias gariepinus) dengan Tekni Probiotik pada Kolam Terpal Di Desa Vokasi
Reksosari, Kecamatan Suruh, Kabupaten Semarang. Pena Akuatik Indonesia. 12(1): 24-32.

Rahmawan, H., Subandiyono dan E. Arini. 2014. Pengaruh Penambahan Ekstrak Pepaya dan Ekstrak Nanas Terhadap Tingkat Pemanfaatan Protein Pakan dan Pertumbuhan Lobster Air Tawar (Cherax Quadricarinatus). J. Of Aquaculture Management and Technology. 3 (4): 75-83.

Setiawati, J.A., Y.T Tarsim, Adiputra dan S. Hudaidah. 2013. Pengaruh Penambahan Probiotik pada Pakan dengan Dosis Berbeda terhadap Pertumbuhan, Kelulushidupan, Efisiensi Pakan dan Retensi Protein Ikan Patin (Pangasius hypophthalamus). E-Jurnal Rekayasa dan Teknologi Budidaya Perairan I (2) : 151-162.

Soedibya, P.H.T. 2013. Retensi Protein pada Ikan Nila GIFT (Oreochromis niloticus) yang diberi Pakan Azola pinnata dengan diperkaya Mikroba Probiotik. J. Akuakultur Ind., 12 (2):109-113.

Srigandono, B. 1992. Rancangan Percobaan. Fakultas Peternakan, Universitas Diponegoro, Semarang, 178 hlm..

Standar Nasional Indonesia. 01-4087. 2006. Pakan Buatan Untuk Ikan Lele Dumbo (Clarias gariepinus) pada Budidaya Intensif. 